This item was submitted to Loughborough's Research Repository by the author.

Items in Figshare are protected by copyright, with all rights reserved, unless otherwise indicated.

\title{
Impact of ICT on the productivity of the firm: evidence from Turkish manufacturing
}

\section{PLEASE CITE THE PUBLISHED VERSION}

https://doi.org/10.1007/s11123-017-0497-3

\section{PUBLISHER}

(C) Springer

VERSION

AM (Accepted Manuscript)

\section{PUBLISHER STATEMENT}

This work is made available according to the conditions of the Creative Commons Attribution-NonCommercialNoDerivatives 4.0 International (CC BY-NC-ND 4.0) licence. Full details of this licence are available at: https://creativecommons.org/licenses/by-nc-nd/4.0/

\section{LICENCE}

CC BY-NC-ND 4.0

\section{REPOSITORY RECORD}

Kilicaslan, Yilmaz, Robin C. Sickles, Aliye Atay Kayis, and Yesim Ucdogruk Gurel. 2019. "Impact of ICT on the Productivity of the Firm: Evidence from Turkish Manufacturing". figshare. https://hdl.handle.net/2134/27075. 


\title{
Forthcoming in the Journal of Productivity Analysis, 2017
}

\section{Impact of ICT on the Productivity of the Firm: \\ Evidence from Turkish Manufacturing}

Yılmaz Kılıçaslan ${ }^{1}$, Department of Economics, Anadolu University, Turkey

ykilicaslan@anadolu.edu.tr

Robin C. Sickles, Department of Economics, Rice University, USA

rsickles@rice.edu

Aliye Atay Kayış, Department of Econometrics, Süleyman Demirel University, Turkey aliyekayis@yahoo.com

Yeşim Üçdoğruk Gürel, Department of Economics, Dokuz Eylül University, Turkey yesim.ucdogruk@deu.edu.tr

\begin{abstract}
This paper aims to explore the impact of Information and Communication Technologies (ICT) on labor productivity growth in Turkish manufacturing. This is the first attempt at exploring the impact of ICT on productivity in Turkish manufacturing at the firm level. The analysis is based on firm level data obtained from Turkish Statistical Institute (TURKSTAT) and covers the period from 2003 to 2012. The data used in the analysis includes all firms employing 19+ workers in Turkish manufacturing industry. Growth accounting results show that the contributions of conventional and ICT capital to value added growth are not significantly different from each other. On the other hand, results based both on static (fixed-effects) and dynamic panel data analysis highlight the positive influence on firms' productivity exerted by ICT capital. The findings show that the impact of ICT capital on productivity is larger by about $25 \%$ to $50 \%$ than that of conventional capital. This contribution of ICT capital is higher than that of non-ICT capital for small sized and low-tech firms. Our findings imply that investing in ICT capital increases firm productivity by increasing the productivity of labor and also that convention growth accounting approaches may not be adequate to identify such linkages.
\end{abstract}

Keywords: Productivity, TFP, ICT, manufacturing industry, Turkey.

JEL Codes: D24, L60, O14.

\footnotetext{
${ }^{1}$ Department of Economics, Faculty of Economics, Anadolu University, 26470, Eskisehir, Turkey. Phone: +90 2223350580 ex: 2648, Fax: +90 222 3201304, e-mail: ykilicaslan@ anadolu.edu.tr

* This study is a part of project BAP-1210E155 supported by the Scientific Research Commission of Anadolu University, Eskişehir, Turkey.
} 


\section{Introduction}

Although economists disagree on many contemporary issues in economics, there is a strong consensus that the primary source of long run economic growth is productivity growth. The theoretical underpinnings of such a perspective have been bolstered by the empirical record of the twentieth century, which has witnessed remarkable productive increases not only in manufacturing but also in the other industries of the world's economies. The contribution of factor accumulation, especially capital, in this productivity increase was quite significant at least until the 1970s, as labor productivity was substantially enhanced via capital accumulation. Productivity growth in most of the developed world, however, has slowed since the 1970s, a time at which IT investment was accelerating worldwide. Observed Nobel Laureate Robert Solow (1987) in The New York Times (12 July 1987) a decade later, "we could see the computer age everywhere but not in the productivity statistics." The slowdown in US productivity growth in the mid-1970s and the widespread adoption of computers, whose price/cycle were dropping at exponential rates, were observed simultaneously (Van Reenen et al., 2006; Hulten, 2001). Productivity growth picked up again, especially in the 1990s, and since that time productivity levels have trended to levels that stand at record highs, both in manufacturing and in many other industries. This development has been mainly attributed to the production and widespread use of Information and Communication Technologies (ICT). There is a broad consensus of governmental agencies and academic researchers that widespread usage of ICT has had a profound impact on the level of productivity. The contribution of ICT to labor productivity and growth was not clear until the mid-1990s. By the end of the nineties, however, the studies exploring the ICT-productivity relations reached almost the same conclusion that ICT was quite important in the U.S. growth resurgence observed especially in the second half of the 1990s (see for example; Oliner and Sichel, 1994; Stiroh, 2002; Jorgenson et al., 2008; Van Ark et al., 2008).

Studies estimating productivity and quantifying the impact of ICT on productivity growth in the economies of the world are widespread. In Turkey, however, the studies examining the ICT impact on both output and productivity are quite limited. The main purpose and novelty of this paper is to explore the impact of ICT on output and productivity growth in Turkish manufacturing. This is very important as the extent of the effects of ICT utilization and production on firm's output and productivity growth in Turkish manufacturing is quite limited, even though the widespread usage of ICT at the firms operating in both manufacturing and in other industries is evident. 
Moreover, due to increased economic importance of ICT in Turkey, proper measurement of its impact is crucial for effective policy making.

In this study, we first use growth accounting method to assess the differences between conventional and ICT capital in contributing to value added growth. We also apply an econometric methodology in estimating the production function and quantifying the effect of ICT capital on labor productivity in Turkish manufacturing. We estimate firm level production functions by means of panel data estimation methodologies applying both fixed-effects and Generalized Method of Moments (GMM) models. We evaluate the intensity of ICT and its impact of productivity using the Annual Industry and Service Statistics Database obtained from Turkish Statistical Institute (TURKSTAT). This database covers all Turkish manufacturing firms employing 19+ workers and provides firm level information on many firm-specific variables for the period 2003 to 2012 .

The paper is organized as follows: Section 2 surveys the theory and empirical literature on the relations between output growth, productivity and ICT. The next section introduces the data set used in exploring the impact of ICT on productivity and briefly puts forward the methodology used to calculate conventional and ICT capital stock. Section 4 first provides a brief statistical analysis where output growth is decomposed into the factor input contributions and then develops the econometric analysis and provides the findings on the impact of ICT on productivity in Turkish manufacturing industry. Finally, Section 5 concludes after a short discussion of the key results from this study and evaluates the policy implications.

\section{Productivity and the Turkish ICT/Productivity Nexus}

Productivity as a measure of the efficiency of production is defined as a ratio of output to inputs used in the production. Labor productivity defined as the ratio of output/value added to the number of workers or of hours worked is a commonly used partial measure of productivity. Widespread utilization of labor productivity is due in part by its ease of implementation, especially in developing countries where data collection protocols make total factor productivity measurement difficult to assess. Total factor productivity (TFP), also called multi-factor productivity, is another and better measure of productivity. TFP obtained as the residual from a production function is said to be a measure of productivity that accounts for the output increase not attributable to the factors of production. 
The methodologies available for productivity estimation are distinguished based on several criteria. A primary criterion involves the level of aggregation and whether the researcher is concerned with aggregate (countries/regions/industry) productivity, or productivity of micro units (firm/plant). ${ }^{2}$ Aggregate studies can be distinguished by the role TFP has in explaining growth dynamics and differences in economic performance across countries. This literature rests largely on the Solow growth theory and typically measured by the Solow residual. This growth accounting methodology has been used to estimate TFP at both aggregate and sector level and dates back to the 1950s (Abramovitz, 1956; Solow, 1957). Although, in Solow's (1957) seminal work, only the inputs of capital and labor were considered, the role of other factors such as human capital accumulation on output growth was recognized by subsequent studies (see for example, Mankiw et al., 1992).

One of the extensions proposed by Jorgenson and Griliches (1967) to growth accounting methodology was to highlight possible errors of aggregation due to differences in the quality of inputs. This problem is also related to the error caused by aggregation of different investment goods by simply adding together their quantities. Therefore, Del Gatto et al. (2008: 964) suggest that an appropriate index of capital services should be constructed by treating each investment good as a separate commodity because of the fact that there are new forms of capital. Thus, including new and improved measures of factors of production is necessary to qualify the differences in input quality. This extension to growth accounting is also important because we witness the alteration in the relative contribution of factor accumulation and technological progress to productivity due to "IT revolution" since $1990 \mathrm{~s}^{3}$.

Given the importance of productivity in the process of economic growth and the positive impact of ICT on productivity, much research effort has been devoted to address the impact of ICT on productivity growth. Empirical studies adopted different methodologies to examine the relationship between ICT and firm performance using firm level data. The first was to use ICT capital stock as a separate capital input in TFP calculation (Brynjolfsson and Hitt, 2001; Hempell, 2002). Another methodology was to include ICT capital as an additional ICT measure, alongside other such ICT measures as internet use or number of employees using ICT (Maliranta and Rouvinen, 2003). The

\footnotetext{
${ }^{2}$ For a detailed study, see Del Gatto et al. (2011).

${ }^{3}$ Zelenyuk (2014) provides a recent study on testing the significance of ICT contribution on the labor productivity distribution of developed countries in 1980-1995.
} 
third included ICT capital stock with measures of organizational change and innovation (Van Leeuwen and Van der Wiel, 2003). The last methodology was to include measures of ICT usage such as computer network use (Atrostic and Nguyen, 2002) or per worker laptops/PCs (Van Reenen et al., 2010) to proxy ICT capital in explaining productivity differentials.

There are some studies calculating TFP growth for the Turkish economy (Saygil1 et al. (2001, 2005), Altuğ and Filiztekin (2006), Altuğ et al. (2008) and Ismihan and Metin-Özcan (2008)). These studies explores the sources of long-term economic growth for Turkey over the period 18802005, identifying different time intervals during which TFP change was somewhat distinct. Altuğ et al. (2008) conclude that TFP growth is low in Turkish economy during 1950-2005 at slightly above 1 per cent per year. The results of the other studies using growth accounting for Turkey are not much different. Saygil1 et al. (2001) found that TFP growth was about -0.29 percent during 1972-79 and 0.44 percent during 1980-2000 for aggregate economy. Altuğ and Filiztekin (2006) found that the contribution of TFP growth to output growth becomes positive in Turkish economy only in the post-1980 period.

Regarding the manufacturing sector in Turkey, there has been a considerable number of studies dealing with productivity (see for example, Krueger and Tuncer, 1982; Yıldırım, 1989; Aydoğuş, 1993; Gökçekuş, 1997; Önder and Lenger, 2003; Zaim and Taşkın, 1997; Taymaz and Saatçi, 1997). There is a list of studies that measure changes in TFP and in its components (technical efficiency) in the Turkish manufacturing industry at the regional level (Önder et al., 2003 and Karadağ, et al., 2005) and for different ownership structures, namely public and private (Zaim and Taşkın, 2001). These studies also differ in their methods of computing productivity (Önder et al. (2003) use stochastic production frontiers, whereas Karadağ, et al. (2005) utilize data envelopment analysis). On the other hand, empirical studies at the plant level investigate productivity changes during increased trade openness and participation in international activities over the period 19842000 (see for example, Taymaz and Yılmaz, 2007; Özler and Yılmaz, 2009 and Taymaz et al., 2009). These studies conclude that after 1988, TFP followed an upward trend until 1993, with an average growth rate of 5\% per year, before it completely stalled after the 1994 economic crisis.

To the best of our knowledge, there seem to be only one study that analyzes the productivity of the Turkish ICT sector, but only for consumer electronics. Taymaz and Yllmaz (2007) examine the evolution of automobile and consumer electronics industries and the role of macroeconomic 
policies since the 1980s in order to explain the factors behind the export performance of these sectors. They find that while consumer electronics industry reflects productivity growth above the average after the mid-1990s, productivity growth performance of Turkish automobile industry turns out to be equal to the average growth of manufacturing.

\section{The Data Characteristics}

The analysis in this research is based on the Annual Industry and Service Statistics Database obtained from Turkish Statistical Institute (TURKSTAT). This database covers all manufacturing firms employing 19+ workers and provides firm level information on many firm-specific variables. We used the 4-digit industry level deflator with 2003 as the base year obtained from TURKSTAT to make the variables measured in monetary values real.

Developing a measure of the stock of capital, $K$, is a challenging exercise because the capital stock variable is not available in the data set but as is typical, the firm's investment and depreciation allowances are. Since the database contains only information on investment, capital stock series are constructed by using the perpetual inventory method. The methodology used proxies the capital stock of the initial year by using the yearly amortization allowances from the Turkish Statistical Institute questionnaire.

Letting $K, I N V$, and $d$ stand for capital, investment and depreciation rate ${ }^{4}$ respectively, the capital stock is measured as follows:

$$
K_{t+1}=K_{t}+I N V_{t+1}-d^{*} K_{t}
$$

To estimate ICT and non-ICT (conventional) capital stock series from investment data separately, we calculate the share of ICT and non-ICT investment in total investment. ICT investment includes office and computing equipment and communication equipment and software investment. The initial capital stock of ICT and non-ICT series are proxied by calculated shares of depreciation allowances. Finally, given the deflated investments and shares of depreciation allowances for different types of capital, we apply the perpetual inventory method to obtain the capital stocks for ICT and non-ICT capital.

\footnotetext{
${ }^{4}$ In calculating the capital stock, in fact, we used three different depreciation rates: $7.5 \%, 10 \%$, and $15 \%$. However, results were quite comparable and we report only those based on the $7.5 \%$ depreciation rate.
} 
[Table 1 about here]

Table 1 illustrates the number of firms in the sample according to size ${ }^{5}$ and technological intensity ${ }^{6}$. The share of firms having ICT expenditure constitutes 68 percent of all firms in our sample. The percentage of firms in all manufacturing with ICT expenses at the beginning of the sample period was 66 percent while in 2012 it had increased to 72 percent. About 55 percent of these firms are small sized enterprises, 36 percent of them are medium-sized enterprises and only 9 percent of them are large-scale enterprises. The percentage of medium sized firms in all manufacturing at the beginning of the sample period was 49 percent but in 2012 the percentage of medium sized firms had increased to 59 percent. Low-tech manufacturing firms with ICT expenses constituted the largest share in our sample (52\%) whereas the share of high-tech manufacturing firms is only 1.7 percent.

[Figure 1 about here]

Figure 1 demonstrates the average of the share of ICT capital and non-ICT capital in total capital structure for the firms in our sample according to their sectoral classification. The share of ICT capital in total capital is higher than that of non-ICT capital in most of the manufacturing sectors except the manufacture of beverages, leather and related products, chemicals and chemical products, fabricated metal products and furniture. This outcome is in line with the classification of ICT-using and producing manufacturing industries prepared by Van Ark et al. (2002). The above listed manufacturing industries are all classified as less-intensive ICT-using industries. Moreover,

\footnotetext{
${ }^{5}$ Number of employees is used as the size criterion. Establishments employing fewer than 50 people are classified as "smallsized enterprise" and establishments employing more than 50 and lower than 250 people are classified as "medium-sized enterprise". "Large-scale enterprises" (LSE) employ 250 or more people.

${ }^{6}$ Classification of NACE Rev. 2 at 3-digit level industries according to technological intensity: (1) High technology intensive industries: basic pharmaceutical products and pharmaceutical preparations (21); computer, electronic and optical products (26); air and spacecraft and related machinery (30.3)

(2) Medium technology intensive industries: chemicals and chemical products (20); fabricated metal products, except machinery and equipment (25); electrical equipment (27); machinery and equipment n.e.c. (28); motor vehicles, trailers and semi-trailers (29); other transport equipment (30 -excluding (30.3)); medical and dental instruments and supplies (32.5), reproduction of recorded media (18.2); coke and refined petroleum products (19); rubber and plastic products (22); other non-metallic mineral products (23); basic metals (24); repair and installation of machinery and equipment (33)

(3) Low technology intensive industries: food products (10); beverages (11); tobacco products (12); textiles (13); wearing apparel (14); leather and related products (15); wood and of products of wood and cork, except furniture; manufacture of articles of straw and plaiting materials (16); paper and paper products (17); printing and reproduction of recorded (18, excluding 18.2); furniture (31); other manufacturing (32, excluding 32.5) (http://epp.eurostat.ec.europa.eu/cache/ITY_SDDS/Annexes/htec_esms_an3.pdf)
} 
the share of ICT capital in total capital is high in the manufacture of motor vehicles, trailers and semi-trailers, wood and products of wood and paper and paper products subsectors with an average of 67 percent. The highest share of non-ICT capital in total capital is attained in the manufacture of chemicals and chemical products subsector with an average of 62 percent.

\section{The Impact of ICT on Output Growth and Productivity}

This section examines the impact of ICT on output and labor productivity in Turkish manufacturing industry by using firm level data over the period 2003-2012. We consider both growth accounting and regression-based approaches in our analysis below.

\section{1. Impact of ICT on Output Growth: A Growth Accounting Approach}

The most direct way to model the impact of ICT on growth is to distinguish capital into two subaggregates, ICT and non-ICT capital, and find the differential impact of ICT capital and non-ICT capital on output growth (O'Mahony and Vecchi, 2005). One would expect additional productivity gains from investing in ICT capital compared to non-ICT capital, conventional capital. Suppose the production function of the $i^{\text {th }}$ firm takes the following Cobb-Douglas type production function with Hicks-neutral technology:

$$
Q_{i t}=A_{i t} F\left(K_{i t}, L_{i t}\right)
$$

where $Q$ is output/value added, $A$ is technology, $K$ is capital, and $L$ is labor, and $i$ and $t$ denote firm and time respectively. Assuming that there are two types of capital: ICT $\left(K^{I}\right)$ and non-ICT capital $\left(K^{N}\right)$, and there is constant returns to scale (see Jorgenson et al., 1987; O'Mahony and Vecchi, 2005 and Schreyer, 2000). Letting lower-case letters denote logarithms, output growth can be decomposed into four components: contribution of TFP, labor input, non-ICT capital and ICT capital inputs.

$$
\Delta q_{i t}=\Delta t f p_{i t}+s_{l i(t, t-1)} \Delta l_{i t}+\left(1-s_{l i(t, t-1)}\right)\left(s_{k i(t, t-1)}^{N} \Delta k_{i t}^{N}+s_{k i(t, t-1)}^{I} \Delta k_{i t}^{I}\right)
$$

where $s_{l i}$ is the share of labor in value added and $s_{k i}^{N}$ and $s_{k i}^{I},\left(s_{k i}^{N}+s_{k i}^{I}=1\right)$, are the shares of ICT and non-ICT capital in total. The shares are the mean value of the two years. In equation (3) the value of $\left[\left(1-s_{l i(t, t-1)}\right)\left(s_{k i(t, t-1)}^{I} \Delta k_{i t}^{I}\right)\right]$ will give the contribution of ICT on output growth. 


\section{2. Impact of ICT on Output Growth: Findings from Growth Accounting}

The findings on the impact of ICT capital on output growth based on the equation (3) above are given in Figure 2. This graph demonstrates a decomposition of value added growth for each sector at the 3-digit level in Turkish manufacturing industry over the period 2004-2012 by distinguishing ICT and non-ICT capital. At a first glance, the contribution of non-ICT capital to the growth of value added appears to be smaller in all of the sectors than growth based on the capital aggregate. Moreover, manufacture of tobacco products (120) sector exhibited the highest gain in ICT capital growth $(8 \%)$ per annum.

[Figure 2 about here]

The contribution of ICT capital to value added growth is larger than the contribution of nonICT capital in some sectors that are less-intensive ICT using manufacturing industries such as manufacture of tobacco (120), textiles (13), products of wood cork, straw and plaiting materials (162), paper and paper products (17), chemicals (especially paint (203) and explosives (205)), nonmetallic mineral products (especially cement (235) and glass (231)), other fabricated metal products (259), manufacture of general purpose machinery (281), manufacture of parts and accessories for motor vehicles (293) and installation of industrial machinery and equipment (332).

The contribution of non-ICT capital to value added growth is more than the contribution of ICT capital in a majority of the sectors, especially in the manufacture of leather and related products (15), refined petroleum products (192), pharmaceutical preparations (212), weapons and ammunition (254), communication equipment (263), manufacture of instruments and appliances for measuring, testing and navigation (265), building of ships and boats (301) and manufacture of furniture (310).

The manufacture of jewelry, bijouterie and related articles (321) and manufacture of tobacco products (120) are the fastest growing sectors in Turkey through decomposition of value added growth. When we evaluate the contribution of factor inputs to productivity by distinguishing between ICT and non-ICT capital, both of the above listed sectors together with manufacture of 
products of wood, cork, straw and plaiting materials (162) and manufacture of pharmaceutical preparations (212) display a high average value added growth/year.

The contribution of non-ICT capital to productivity is higher than the contribution of ICT capital in manufacture of pharmaceutical preparations (212) and jewelry, bijouterie and related articles (321) sectors. In manufacture of tobacco products (120) and products of wood, cork, straw and plaiting materials (162) sectors, ICT capital accumulation is higher than the non-ICT capital accumulation. Finally, the contribution of non-ICT capital to value added growth was found to be negative and higher than ICT capital in the manufacture of military fighting vehicles (304) sector.

It is hard to say that ICT capital accumulation has a significant role in the improvement of value added growth in Turkish manufacturing industry. The growth rate of value added in Turkish manufacturing industry was mainly triggered by factors other than ICT capital accumulation. There are some sectors where the impact of ICT capital accumulation is higher than that of the other sectors in the average. These positive and significant contributions of ICT capital are attained in manufacture of tobacco (120), manufacture products of wood cork, straw and plaiting materials (162), manufacture of general purpose machinery (281) and installation of industrial machinery and equipment (332). The highest rate for ICT capital contribution to productivity growth is in manufacture of tobacco products (120) with $8 \%$ growth rate per annum.

\section{3. Modeling the Impact of ICT on Productivity: An Econometric Approach}

There are several problems with growth accounting methodology or index number methods. In particular, they describe productivity patterns but do not provide a model in which to evaluate or interpret causal connections between changes in inputs. With constant returns to scale, typical growth accounting methods measure the contribution of ICT capital to productivity growth by its expenditure share in production. In addition, in the presence of externalities related to factors such as knowledge spillovers from human capital, the contribution of these factors to the productivity is said to be underestimated because they will be included in the residual (Sianesi and Van Reenen (2003). Finally, the typical growth accounting paradigm is a static long-run equilibrium not taking the adjustment costs into account (Van Reenen et al., 2010).

An alternative that can address this issue is an econometric model and we use such an alternative in our analysis below to explore the impact of ICT on labor productivity. In order to check for the 
impact of ICT on output growth, we begin with the Cobb-Douglas production function specification:

$$
Q_{i t}=A_{i t} L_{i t}^{\beta_{L}} K_{i t}^{\beta_{K}}
$$

Labeling the disaggregated capital input as ICT $\left(K^{I}\right)$ and non-ICT capital $\left(K^{N}\right)$ equation (4) can be written as (O’Mahony and Vecchi, 2005 and Van Beveren, 2012):

$$
q_{i t}=\beta_{0}+\beta_{l} l_{i t}+\beta_{k}^{N} k_{i t}^{N}+\beta_{k}^{I} k_{i t}^{I}+\varepsilon_{i t}
$$

Dividing the equation (5) by labor will yield labor productivity:

$$
L P_{i t}=\beta_{0}+\beta_{k}^{N}(k-l)_{i t}^{N}+\beta_{k}^{I}(k-l)_{i t}^{I}+\varepsilon_{i t}
$$

One of the main generic issues related to the estimation of productivity specifications is the problem of unobserved heterogeneity due to the fact that there are many other factors associated with productivity that we cannot observe and measure. The idiosyncratic characteristics about the management of each firm - the skill of the managers, specific know-how, corporate culture, and the capacity to acquire intangible resources - could have a significant influence on productivity (Badescua and Garces-Ayerbe, 2009: 125). Unobserved firm specific factors positively associated with ICT capital, like those for firms with innovative ability that are likely to invest more in ICT, will cause the coefficient $\beta_{k}^{I}$ to be biased upward (Van Reenen et al., 2010). Fixed effects may address in part the unobserved heterogeneity (these can be viewed as instrumental variables) but the endogeneity of input decisions also suggests an IV procedure. The inputs used in the production are chosen by firms and may not be exogenous. In economic terms this means that inputs cannot be chosen in reaction to productivity shocks that is not likely to hold in practice (Van Beveren, 2012: 106). The techniques for dealing with this latter issue utilize instruments that are based on the lagged values of the dependent and independent variables (see for a detailed discussion, Blundell and Bond, 1998 and 2000; Olley and Pakes, 1996). We will employ those instruments using generalized methods of moments (GMM) method to deal with the endogeneity problem. Specifically, after first-differencing the production function to address the potential fixed effects, we use lagged levels of inputs as instruments for changes in the inputs (Wooldridge, 2009).

The formal specification of the GMM model to be estimated is thus modified to:

$$
q_{i t}=\beta_{0}+\beta_{q} q_{i, t-1}+\beta_{l} l_{i t}+\beta_{k}^{N} k_{i t}^{N}+\beta_{k}^{I} k_{i t}^{I}+\varepsilon_{i t}
$$


Note that Equation (7) may also be transformed to reflect the impact of ICT on labor productivity $(L P)$ by dividing by the labor input:

$$
L P_{i t}=\beta_{0}+\beta_{q}(q-l)_{i, t-1}+\beta_{k}^{N}(k-l)_{i t}^{N}+\beta_{k}^{I}(k-l)_{i t}^{I}+\varepsilon_{i t}
$$

The estimated value of $\beta_{k}^{I}$ will give the impact of ICT on output growth in equation (8) and on labor productivity in equation (8). This coefficient indeed is the elasticity of productivity with respect to ICT-capital. We expect this coefficient to be statistically significant and higher than that of non-ICT capital coefficient $\beta_{k}^{N}$.

\subsection{The Impact of ICT on Productivity: Estimation Results}

Table 2 summarizes the data for the entire sample and for each size and technology intensity group individually. The dependent variable estimated in the model is labor productivity in logarithmic form. The mean value of labor productivity is the highest in high-tech manufacturing firms. Moreover, large-scale firms also have the highest mean value compared to all other size classifications. The mean values for ICT and non-ICT capital also become higher as firms get larger in scale and have a higher technological intensity.

[Table 2 about here]

Table 3 demonstrates the impact of ICT on productivity for all firms in the sample by different estimation methods. The first model used in order to evaluate the impact of ICT on labor productivity specifies the firm-specific heterogeneity as uncorrelated random effects. . The estimated coefficient of ICT capital is significant and positively related with labor productivity. Moreover, while there is a significant and positive estimated relationship between productivity and ICT and non-ICT capital, the results show that the coefficient of ICT capital is close to that of nonICT capital. This implies that ICT capital is as productive as conventional capital. We also test for random effects by using Breusch-Pagan Lagrange multiplier (LM) test. We reject the null hypothesis that variances across entities are zero hence there is significant difference across units (i.e. panel effect). 
The second estimation method that is utilized for evaluation of the ICT impact on productivity specifies the firm specific heterogeneity as correlated random effects with the effects correlated with all of the mean values of the regressors, i.e., heterogeneity is treated by classical "fixed effects". There is a significant and positive estimated relationship between productivity and ICT and non-ICT capital. Moreover, the results show that the coefficient of ICT capital is larger than that of non-ICT capital indicating that ICT capital is more productive.

The last estimation method is two-step GMM two-step, wherein we investigate heterogeneity in the adjustment dynamics among different types of firms. Instruments for the differenced equation include the lagged values of labor productivity and capital and labor inputs. Lagged labor productivity is significant and positively related with productivity, validating the importance of adjustment dynamics in the model. Both ICT capital and non-ICT capital are inducing labor productivity. But the magnitude of the effect of ICT capital is smaller than that of non-ICT capital. Regarding the test for autocorrelation, the estimated models present no significant evidence of serial correlation in the first-differenced errors at order 2.

[Table 3 about here]

Another worthwhile exercise will be to analyze the impact of ICT on productivity according to different size and technology intensity classes, since in the descriptive analysis we find that the ICT capital structure improves with size and technology intensity of firms. Table 4 demonstrates the impact of ICT on productivity by different size classes. We also employ all three estimation methods previously used in Table 3. The estimated coefficient of ICT capital is significant and positively related with labor productivity regardless of size classes. The ICT capital is as productive as conventional capital in small sized firms. The only larger impact of ICT capital compared to non-ICT capital is attained in small sized firms with the fixed effects estimator. The magnitude of coefficient for non-ICT capital becomes larger in medium size firms in GMM estimation.

Table 5 demonstrates the impact of ICT on productivity by different technology intensity classes. The table demonstrates the estimation results for fixed effects, random effects and GMM 
estimation methods. The estimated coefficient of ICT capital is significant and positively related with labor productivity regardless of technology intensity classes. The ICT capital is more productive than conventional capital in low-tech firms for both random and fixed effects estimators. The only larger impact of ICT capital compared to non-ICT capital is attained in high-tech firms with the fixed effects estimator. The magnitude of the coefficient for ICT capital is also larger than that of non-ICT capital in high-tech firms when we employ a dynamic model specification that utilizes lagged labor productivity.

[Table 4 about here]

[Table 5 about here]

\section{Conclusion and Policy Implications}

This study examines the dynamics and sources of value added and productivity growth in Turkish manufacturing industry using firm level data. The analysis is based on the firm level data obtained from TURKSTAT (2015) that provides significant evidences for Turkish manufacturing industry in 2000s. This study is the first attempt in quantifying the difference between ICT and conventional capital's contribution to Turkish output growth by using growth accounting methodology, and to estimate the impact of ICT on labor productivity using both static (fixed-effects) and dynamic panel data model. Moreover, the possible differences in the impact of ICT capital on productivity are evaluated for the firms with different size and technology intensity.

The findings of this research based on growth accounting results suggest that ICT capital accumulation has no special role vis-a-vis non-ICT capital in contributing to value added growth in the Turkish manufacturing industry during 2004-2012. The highest contribution of ICT capital to output growth is in the manufacture of tobacco products (120) sector. There are some sectors where ICT capital substituted for non-ICT capital. These sectors are manufacture of textiles (13), products of wood cork, straw and plaiting materials (162), paper and paper products (17), chemicals 
(especially paint (203) and explosives (205)), non-metallic mineral products (especially cement (235) and glass (231)), other fabricated metal products (259), manufacture of general purpose machinery (281), manufacture of parts and accessories for motor vehicles (293) and installation of industrial machinery and equipment (332). Moreover, the higher contribution of ICT capital to output growth is attained in less-intensive ICT using sectors. Moreover, the above stated sectors classified as medium technology intensive sectors (except manufacture of textiles, products of wood cork, straw and plaiting materials and paper and paper products).

Our findings based on both static and dynamic panel data models, on the other hand, show that ICT capital is more productivity enhancing than conventional capital. The contribution of ICT capital to labor productivity in Turkish manufacturing industry is larger about $25 \%$ to $50 \%$ than that of conventional capital. This contribution of ICT capital is higher than that of non-ICT capital for small sized and low-tech firms.

The results of growth accounting and econometric estimations do not lead to the same conclusion that investing more in ICT capital enhances productivity growth. The reason rests with the interpretation of the two approaches. First is that ICT capital accumulation does not increase the growth of output directly but increases the productivity of labor. Therefore we found higher impact of ICT capital accumulation on labor productivity growth but not on value added growth. Second is that while growth accounting may capture some of the direct effects of ICT resulting from ICT capital deepening and TFP increase in ICT producing sector, it's unable to quantify the indirect effects of ICT such as productivity enhancement in ICT using industries due to investment and diffusion of ICT (Biagi, 2013).

This research concludes that ICT capital is more productive than conventional capital. This leads to the policy suggestion that encouraging the firms to invest and use more ICT intensive capital may bring about further productivity gains. The question here is how to encourage the firms to invest and use ICT capital. We argue, in this study, that there might be some roles for public policies to support investment in ICT. These policies may include supporting R\&D in the ICT producing sector, promoting use of ICT in ICT using sector, direct public investment in ICT, and subsidies that regulates price of ICT. 


\section{References}

Abramovitz, M. (1956) Resource and output trends in the United States since 1870, American Economic Review, 46(2), 5-23.

Altuğ, S. and Filiztekin, A. (2006) Productivity and growth, 1923-2003, in S. Altuğ and A. Filiztekin (eds.), The Turkish Economy: The Real Economy, Corporate Governance, and Reform. London: Routledge Studies in Middle Eastern Economics.

Altuğ, S., Filiztekin, A. and Pamuk, Ş. (2008) Sources of long-term economic growth for Turkey, 1880-2005, European Review of Economic History, 12, 393-430. doi: $\underline{10.1017 / \mathrm{S} 1361491608002293}$

Atrostic, K. and Nguyen, V. (2002) Computer Networks and US Manufacturing Plant Productivity: New Evidence from the CNUS Data, Center for Economic Studies, CES Working Paper 0201.

Aydoğuş, O. (1993) Türkiye imalat sanayiinde ithal ikamesi, ihracat artışı ve toplam faktör verimliliği ilişkileri: 1971-88, METU Studies in Development, 20, 453-473.

Badescua, M. and Garces-Ayerbeb, C. (2009) The impact of information technologies on firm productivity: Empirical evidence from Spain, Technovation, 29, 122-129. doi: 10.1016/j.technovation.2008.07.005

Beveren, I. V. (2012) Total Factor Productivity Estimation: A Practical Review, Journal of Economic Surveys, 26(1), pp. 98-128. doi: 10.1111/j.1467-6419.2010.00631.x

Blundell, R. and Bond, S. (1998) Initial conditions and moment restrictions in dynamic panel data models, Journal of Econometrics, 87, 115-143. doi: 10.1016/S0304-4076(98)00009-8

Blundell, R. and Bond, S. (2000) GMM estimation with Persistent Panel Data: An Application to Production Functions, Econometric Review, 19(3), 321-340. doi: $\underline{10.1080 / 07474930008800475}$

Brynjolfsson, E. and Hitt, M. (2001) Computing Productivity: Firm-Level Evidence, MIT Sloan Working Paper, No. 4210-01.

Del Gatto, M., Pagnini, M. and Ottaviano, G.I.P. (2008) Openness to trade and industry cost dispersion: Evidence from a panel of Italian Firms, Journal of Regional Science, 48(1), 97129. doi: $10.1111 /$ j.1467-9787.2008.00546.x

Del Gatto, M., Liberto , A. and Petraglia, C. (2011) Measuring Productivity, Journal of Economic Surveys, 25(5), 952-1008. doi : 10.1111/j.1467-6419.2009.00620.x

Gökçekuş, Ö. (1997) Trade liberalization and productivity growth: new evidence from the Turkish rubber industry, Applied Economics, 29, 639-645. doi: $\underline{\text { 10.1080/000368497326831 }}$

Hempell T. (2002) Does Experience Matter? Productivity effects of ICT in the German service sector, Centre for European Economic Research, Discussion paper 02-43, Manheim. 
Hulten, Charles R. (2001) Total Factor Productivity: A Short Biography, in New Developments in Productivity Analysis, Eds: Hulten, Charles R., Dean, Edwin R.; Harper, Michael J., USA: University of Chicago Press. pp. 1-54.

Ismihan, M. and K. Metin-Ozcan (2008) The Growth Performance of the Turkish Economy: 19602004, Bilkent University, Department of Economics Discussion Papers, No. 08-01, Ankara, Bilkent.

Jorgenson, D. and Griliches, Z. (1967) The explanation of productivity change, Review of Economic Studies, 34(3), 249-283.

Jorgenson, D. W., Gollop, F. M. and Fraumeni, B. (1987) Productivity and US Economic Growth, Cambridge, Mass.: Harvard University Press.

Jorgenson D.W., Ho M.S. and Stiroh K.J. (2008) A Retrospective Look at the U.S. Productivity Growth Resurgence, Journal of Economic Perspectives, 22 (1), 3-24.

Karadağ, M., Önder, Ö. and Lenger, A. (2005) Growth of TFP in the Turkish Manufacturing Industry at Provincial Level, Regional Studies, 39(2), 213-223. doi: $\underline{10.1080 / 003434005200060007}$

Krueger, A. and Tuncer, B. (1982) Growth of factor productivity in Turkish manufacturing industries, Journal of Development Economics, 11, 307-325.

Mankiw, N. G., Romer, D. and Weil, D. (1992) A contribution to the empirics of economic growth, Quarterly Journal of Economics, 107, 407-37. doi: 10.2307/2118477

Oliner, S. D. and Sichel, D. (1994) Computers and Output Growth: How Big is the Puzzle?' Brookings Papers in Economic Activity, 2, 273-334.

Olley, S. and Pakes, A. (1996) The dynamics of productivity in the telecommunications equipment industry, Econometrica, 64(6), 1263-1297. 10.3386/w3977

O’Mahony, M. and Vecchi, M. (2005) Quantifying the Impact of ICT Capital on Output Growth: A Heterogeneous Dynamic Panel Approach, Economica, 72, 615-633. doi: 10.1111/j.1468$\underline{0335.2005 .0435 . \mathrm{x}}$

Önder, Ö. and Lenger, A. (2003) Productivity in Turkish manufacturing industry: a comparative analysis on the basis of selected provinces, Yapı Kredi Economic Review, 14, 17-29.

Önder, Ö. Deliktaș, E. and Lenger, A. (2003) Efficiency in the Manufacturing Industry of Selected Provinces in Turkey: A Stochastic Frontier Analysis, Emerging Markets Finance \& Trade, 39(2), 98-113.

Özler, Ş. and K. Y1lmaz (2009) Productivity response to reduction in trade barriers: evidence from Turkish manufacturing plants, Review of World Economics, 145, 339-360. doi: $\underline{10.1007 / \mathrm{s} 10290-009-0019-0}$ 
Sayg1lı, S., Cihan, C. and Yurtoğlu, H. (2001) Productivity and growth in OECD countries: an assessment of the determinants of productivity, Yapı Kredi Economic Review, 12, 49-64.

Saygıl1, S., Cihan, C. and Yurtoğlu, H. (2005). Türkiye Ekonomisinde Sermaye Birikimi, Büyüme ve Verimlilik 1972-2003, State Planning Organization Publication, Number 2686, Ankara.

Schreyer, P. (2000). The Contribution of Information and Communication Technology to Output Growth: A Study of the G7 Countries, STI Working Paper no. 2000/2.

Sianesi, B. and Van Reenen, J. (2003) Education and Economic Growth: A Review of the Literature, Journal of Economic Surveys, 17(2), 157-200.

Solow, R. (1957) Technical change and the aggregate production function, Review of Economics and Statistics, 39(3), 312-320.

Solow, R. (1987) 'We'd Better Watch Out', New York Times Book Review, July 12, 36.

Stiroh, K. (2002) Are ICT Spillovers Driving the New Economy?, Review of Income and Wealth, 48(1), 33-57.

Taymaz, E., and Saatçi, G. (1997) Technical Change and Efficiency in Turkish Manufacturing Industries, Journal of Productivity Analysis, 8(4), 461-475. doi: 10.1023/A:1007796311574

Taymaz, E. and Y1lmaz, K. (2007) Productivity and trade orientation: Turkish manufacturing industry before and after the customs union, The Journal of International Trade and Diplomacy, 1(1), 127-154.

Taymaz, E. and Yilmaz, K. (2007) Integration with the Global Economy The Case of Turkish Automobile and Consumer Electronics Industries, mimeo.

Taymaz, E., Voyvoda, E. and Yilmaz K. (2009) Transition to Democracy, Real Wages and Productivity: Evidence from the Turkish Manufacturing Industry, mimeo.

TURKSTAT (2015) Annual Industry and Service Statistics, Turkish Statistical Institute, Ankara.

Van Ark, B., Inklaar, R. and McGuckin, R.H. (2002) 'Changing Gear', Productivity, ICT and Service Industries: Europe and the United States', GGGD Research Memorandum, no. GD60, downloadable from: www.eco.rug.nl/ggdc/ pub/online/gd60(online).pdf.

Van Ark, B; O'Mahoney, M and Timmer, M (2008) The Productivity Gap Between Europe and the United States: Trends and Causes, Journal of Economic Perspectives, 22(1), 25-44

Van Beveren, I. (2012) Total Factor Productivity Estimation: A Practical Review, Journal of Economic Surveys, 26 (1), 98-128. doi: 10.1111/j.1467-6419.2010.00631.x

Van der Wiel, H. and Van Leeuwen, G. (2004) ICT and Productivity, In: Fostering Productivity, Patterns, Determinants and Policy Implications. Contributions to Economic Analysis no. 263, Elsevier, the Netherlands, $93-112$.

Van Reenen, J., M. Draca, M. and Sadun, R. (2006) Productivity and ICT: A Review of the Evidence, CEP Discussion Paper, No 749. 
Van Reenen, J., Bloom, N., Draca, M., Kretschmer, T. and Sadun, R. (2010) The Economic Impact of ICT, SMART N. 2007/0020, Enterprise LSE.

Wooldridge, J.M. (2009) On estimating firm-level production functions using proxy variables to control for unobservables, Economics Letters, 104(3), 112-114. doi: 10.1016/j.econlet.2009.04.026

Yıldırım, E. (1989) Total factor productivity growth in Turkish manufacturing industry between 1963 1983: an analysis, METU Studies in Development, 16, 65-69.

Zaim, O., and Taşkın, F. (1997) The Comparative Performance of Public Enterprise Sector in Turkey: A Malmquist Productivity Index Approach, Journal of Comparative Economics, 25(2), 129-157. doi: 10.1006/jcec.1997.1459

Zaim, O., and Taşkın, F. (2001) The Relative Efficiency of the Public Manufacturing Industry in Turkey: An Intertemporal Analysis Using Parametric and Nonparametric Production Frontiers, In Celasun M. (ed.) State-Owned Enterprises in the Middle East and North Africa: Privatisation, Performance and Reform, Rutledge, London, 275-290.

Zelenyuk, V. (2014) Testing Significance of Contributions in Growth Accounting with Application to Testing ICT impact on Labor Productivity of Developed Countries, International Journal of Business and Economics, 13 (2), 115-126. 
Table 1. Number of Firms

\begin{tabular}{rrrrrrrrr}
\hline \hline & All & ICT capital exp. & Low-tech & Medium-tech & High-tech & $\mathbf{1 9 - 4 9}$ & $\mathbf{5 0 - 2 4 9}$ & $\mathbf{2 5 0 +}$ \\
\hline $\mathbf{2 0 0 3}$ & 8081 & 5373 & 2873 & 2383 & 117 & 2634 & 2121 & 618 \\
$\mathbf{2 0 0 4}$ & 10917 & 7237 & 3824 & 3255 & 158 & 3684 & 2762 & 791 \\
$\mathbf{2 0 0 5}$ & 15487 & 10070 & 5214 & 4679 & 177 & 5806 & 3358 & 906 \\
$\mathbf{2 0 0 6}$ & 17782 & 12688 & 6601 & 5870 & 217 & 7508 & 4165 & 1015 \\
$\mathbf{2 0 0 7}$ & 17899 & 12016 & 6146 & 5670 & 200 & 6563 & 4371 & 1082 \\
$\mathbf{2 0 0 8}$ & 17771 & 11412 & 5731 & 5480 & 201 & 5860 & 4464 & 1088 \\
$\mathbf{2 0 0 9}$ & 16180 & 10870 & 5488 & 5184 & 198 & 5600 & 4285 & 985 \\
$\mathbf{2 0 1 0}$ & 21454 & 15153 & 7711 & 7206 & 236 & 8765 & 5232 & 1156 \\
$\mathbf{2 0 1 1}$ & 24218 & 17738 & 9053 & 8449 & 236 & 10574 & 5844 & 1320 \\
$\mathbf{2 0 1 2}$ & 27075 & 19203 & 9974 & 8993 & 236 & 11326 & 6436 & 1441 \\
\hline \hline
\end{tabular}

Source: Authors calculations based on TURKSTAT (2015) data. 
Table 2. Descriptive statistics

\begin{tabular}{|c|c|c|c|c|c|c|c|}
\hline & All & Low-tech & Medium-tech & High-tech & $19-49$ & $50-249$ & $250+$ \\
\hline \multicolumn{8}{|c|}{ Labor productivity (log) } \\
\hline Mean & 9.48 & 9.39 & 9.55 & 10.38 & 9.35 & 9.59 & 10.06 \\
\hline Std. Deviation & 1.18 & 1.10 & 1.24 & 1.48 & 1.16 & 1.17 & 1.22 \\
\hline Min & -13.73 & -11.96 & -13.73 & -11.65 & -12.31 & -13.73 & -12.31 \\
\hline Max & 15.03 & 13.94 & 14.95 & 15.03 & 15.03 & 14.02 & 13.58 \\
\hline \multicolumn{8}{|l|}{ ICT capital } \\
\hline Mean & 8.68 & 8.59 & 8.76 & 9.43 & 8.26 & 9.19 & 10.08 \\
\hline Std. Deviation & 3.10 & 3.13 & 3.06 & 2.99 & 3.37 & 2.51 & 2.07 \\
\hline Min & -2.74 & -2.74 & -2.04 & 0.00 & -2.74 & -2.04 & -2.29 \\
\hline Max & 16.19 & 16.19 & 15.70 & 14.60 & 15.70 & 15.27 & 16.19 \\
\hline \multicolumn{8}{|l|}{ Non-ICT capital } \\
\hline Mean & 8.64 & 8.53 & 8.72 & 9.76 & 8.26 & 9.05 & 9.91 \\
\hline Std. Deviation & 2.40 & 2.41 & 2.40 & 1.94 & 2.54 & 2.11 & 1.61 \\
\hline Min & -12.75 & -3.78 & -12.75 & 0.00 & -12.75 & -3.78 & -0.95 \\
\hline Max & 17.12 & 17.12 & 16.29 & 14.11 & 16.18 & 16.29 & 17.12 \\
\hline
\end{tabular}

Source: Authors calculations based on TURKSTAT (2015) data. 
Table 3. The impact of ICT on productivity, 2003-2012: Random effects, Fixed effects and GMM estimation results

\begin{tabular}{lccc}
\hline \hline Dependent variable: labor productivity & & & \\
& Random effects & Fixed effects & GMM \\
\hline Lagged labor productivity & & & $(0.0072)$ \\
& & & $0.0345^{* * * *}$ \\
ICT capital & $0.0633^{* * * *}$ & $0.0476^{* * *}$ & $(0.0058)$ \\
& $(0.0017)$ & $(0.0025)$ & $0.0494^{* * *}$ \\
Non-ICT capital & $0.0646^{* * *}$ & $0.0316^{* * *}$ & $(0.0060)$ \\
& $(0.0018)$ & $(0.0029)$ & $7.875^{* * *}$ \\
Constant & $8.229^{* * *}$ & $8.729 * * *$ & $(0.0949)$ \\
& $(0.0195)$ & $(0.0273)$ & 97111 \\
\hline Observations & 162926 & 162926 & 22725 \\
Number of firms & 35184 & 35184 & $1134.51[11]$ \\
\hline Wald statistics $(d f)$ & $4633.42[11]$ & & \\
F statistics $(d f)$ & & $148.79[11]$ & \\
Residuals $(p-$ values $)$ & & & -30.315 \\
AR(1) & & & 0.000 \\
& & & -0.6849 \\
AR(2) & & & 0.4934 \\
\hline \hline
\end{tabular}

All equations include year dummies.

Robust standard errors in parentheses; *** $\mathrm{p}<0.01, * * \mathrm{p}<0.05, * \mathrm{p}<0.1$

Source: Authors calculations based on TURKSTAT (2015) data. 
Table 4. The impact of ICT on productivity according to size, 2003-2012: Random effects, Fixed effects and GMM estimation results

\begin{tabular}{|c|c|c|c|c|c|c|c|c|c|}
\hline \multicolumn{10}{|c|}{ Dependent variable: labor productivity } \\
\hline & \multicolumn{3}{|c|}{ Random effects } & \multicolumn{3}{|c|}{ Fixed effects } & \multicolumn{3}{|c|}{ GMM } \\
\hline & $19-49$ & $50-249$ & $250+$ & $19-49$ & $50-249$ & $250+$ & $19-49$ & $50-249$ & $250+$ \\
\hline $\begin{array}{l}\text { Lagged labor } \\
\text { productivity }\end{array}$ & & & & & & & $\begin{array}{c}0.0656 * * * \\
(0.0098)\end{array}$ & $\begin{array}{c}0.112 * * * \\
(0.0116)\end{array}$ & $\begin{array}{c}0.162 * * * \\
(0.0284)\end{array}$ \\
\hline ICT capital & $\begin{array}{c}0.0596 * * * \\
(0.0019)\end{array}$ & $\begin{array}{c}0.0656^{* * *} \\
(0.0036)\end{array}$ & $\begin{array}{c}0.0697 * * * \\
(0.0113)\end{array}$ & $\begin{array}{c}0.0404 * * * \\
(0.0030)\end{array}$ & $\begin{array}{c}0.0330 * * * \\
(0.0051)\end{array}$ & $\begin{array}{c}0.0205 \\
(0.0145)\end{array}$ & $\begin{array}{c}0.0279 * * * \\
(0.0069)\end{array}$ & $\begin{array}{c}0.0324 * * * \\
(0.0099)\end{array}$ & $\begin{array}{c}0.0674 * * * \\
(0.0150)\end{array}$ \\
\hline Constant & $\begin{array}{c}8.287 * * * \\
(0.0226) \\
\end{array}$ & $\begin{array}{c}8.131 * * * \\
(0.0376) \\
\end{array}$ & $\begin{array}{c}8.149 * * * \\
(0.111) \\
\end{array}$ & $\begin{array}{c}8.691 * * * \\
(0.0343) \\
\end{array}$ & $\begin{array}{c}8.871 * * * \\
(0.0521) \\
\end{array}$ & $\begin{array}{c}9.491 * * * \\
(0.147) \\
\end{array}$ & $\begin{array}{c}8.118^{* * * *} \\
(0.124) \\
\end{array}$ & $\begin{array}{c}7.619 * * * \\
(0.150) \\
\end{array}$ & $\begin{array}{c}6.934 * * * \\
(0.412) \\
\end{array}$ \\
\hline Observations & 98052 & 53363 & 11511 & 98052 & 53363 & 1,511 & 50806 & 37395 & 8910 \\
\hline Number of firms & 28754 & 13453 & 2291 & 28754 & 13453 & 2291 & 15882 & 10294 & 1963 \\
\hline Wald statistics $(d f)$ & $\begin{array}{c}2785.93 \\
{[11]}\end{array}$ & $\begin{array}{c}1752.64 \\
{[11]}\end{array}$ & $\begin{array}{c}368.30 \\
{[11]}\end{array}$ & & & & $\begin{array}{c}575.40 \\
{[11]}\end{array}$ & $\begin{array}{c}514.15 \\
{[11]}\end{array}$ & $\begin{array}{c}253.79 \\
{[11]}\end{array}$ \\
\hline$A R(2)$ & & & & & & & $\begin{array}{c}-1.5231 \\
0.1277\end{array}$ & $\begin{array}{l}1.4594 \\
0.1445\end{array}$ & $\begin{array}{c}-0.6349 \\
0.5255\end{array}$ \\
\hline
\end{tabular}

All equations include year dummies.

Robust standard errors in parentheses; *** $\mathrm{p}<0.01, * * \mathrm{p}<0.05, * \mathrm{p}<0.1$

Source: Authors calculations based on TURKSTAT (2015) data. 
Table 5. The impact of ICT on productivity according to technology intensity classification, 2003-2012: Random effects, Fixed effects and GMM estimation results

\begin{tabular}{|c|c|c|c|c|c|c|c|c|c|}
\hline \multicolumn{10}{|c|}{ Dependent variable: labor productivity } \\
\hline & \multicolumn{3}{|c|}{ Random effects } & \multicolumn{3}{|c|}{ Fixed effects } & \multicolumn{3}{|c|}{ GMM } \\
\hline & Low-tech & $\begin{array}{l}\text { Medium- } \\
\text { tech }\end{array}$ & High-tech & Low-tech & $\begin{array}{l}\text { Medium- } \\
\text { tech }\end{array}$ & $\begin{array}{l}\text { High- } \\
\text { tech }\end{array}$ & Low-tech & $\begin{array}{l}\text { Medium- } \\
\text { tech }\end{array}$ & High-tech \\
\hline Lagged labor produc & & & & & & & $\begin{array}{c}0.107 * * * \\
(0.0091)\end{array}$ & $\begin{array}{c}0.0967 * * * \\
(0.0119)\end{array}$ & $\begin{array}{c}0.0437 \\
(0.0809)\end{array}$ \\
\hline ICT capital & $\begin{array}{c}0.0614 * * * \\
(0.0022)\end{array}$ & $\begin{array}{c}0.0640 \text { **** } \\
(0.0028)\end{array}$ & $\begin{array}{c}0.0533^{* * *} * \\
(0.0186)\end{array}$ & $\begin{array}{c}0.0542 * * \\
* \\
(0.0034) \\
0.0160 * *\end{array}$ & $\begin{array}{c}0.0414 * * * \\
(0.0037)\end{array}$ & $\begin{array}{c}0.0394 \\
(0.0262)\end{array}$ & $\begin{array}{c}0.0331 * * * \\
(0.0093)\end{array}$ & $\begin{array}{c}0.0320^{* * *} \\
(0.0065)\end{array}$ & $\begin{array}{c}0.0477^{* *} \\
(0.0189)\end{array}$ \\
\hline Non-ICT capital & $\begin{array}{c}0.0526 * * * \\
(0.0023)\end{array}$ & $\begin{array}{c}0.0767 * * * \\
(0.0029)\end{array}$ & $\begin{array}{c}0.0664 * * * \\
(0.0212)\end{array}$ & $\begin{array}{c}* \\
(0.0041)\end{array}$ & $\begin{array}{c}0.0467 * * * \\
(0.0043)\end{array}$ & $\begin{array}{c}0.0288 \\
(0.0283)\end{array}$ & $\begin{array}{c}0.0482 * * * \\
(0.0093)\end{array}$ & $\begin{array}{c}0.0544 * * * \\
(0.0073)\end{array}$ & $\begin{array}{c}0.0263 \\
(0.0240)\end{array}$ \\
\hline Constant & $\begin{array}{c}8.287 * * * \\
(0.0244) \\
\end{array}$ & $\begin{array}{l}8.172 * * * \\
(0.0311) \\
\end{array}$ & $\begin{array}{c}9.067 * * * \\
(0.238) \\
\end{array}$ & $\begin{array}{c}8.768 * * * \\
(0.0367) \\
\end{array}$ & $\begin{array}{c}8.679 * * * \\
(0.0413)\end{array}$ & $\begin{array}{c}9.387 * * * \\
(0.274) \\
\end{array}$ & $\begin{array}{c}7.646^{* * * *} \\
(0.128)\end{array}$ & $\begin{array}{c}7.827 * * * \\
(0.142) \\
\end{array}$ & $\begin{array}{c}9.149 * * * \\
(0.907) \\
\end{array}$ \\
\hline $\begin{array}{l}\text { Observations } \\
\text { Number of firms }\end{array}$ & $\begin{array}{l}86787 \\
19117\end{array}$ & $\begin{array}{l}73694 \\
16072\end{array}$ & $\begin{array}{c}2444.00 \\
517\end{array}$ & $\begin{array}{l}86787 \\
19117\end{array}$ & $\begin{array}{l}73694 \\
16072\end{array}$ & $\begin{array}{c}2444 \\
517\end{array}$ & $\begin{array}{l}51348 \\
12173\end{array}$ & $\begin{array}{l}44245 \\
10527\end{array}$ & $\begin{array}{c}1517 \\
359\end{array}$ \\
\hline $\begin{array}{l}\text { Wald statistics (df) } \\
\text { F statistics (df) } \\
\text { Residuals (p- } \\
\text { values) }\end{array}$ & $\begin{array}{c}2283.32 \\
{[11]}\end{array}$ & $2336.10[11]$ & $\begin{array}{c}105.05 \\
{[11]}\end{array}$ & $70.25[11]$ & $81.12[11]$ & $7.18[11]$ & $\begin{array}{c}540.73 \\
{[11]}\end{array}$ & $662.94[11]$ & $\begin{array}{c}77.16 \\
{[11]}\end{array}$ \\
\hline $\operatorname{AR}(1)$ & & & & & & & $\begin{array}{l}-21.9 \\
0.000\end{array}$ & $\begin{array}{c}-20.802 \\
0.000\end{array}$ & $\begin{array}{c}-3.6448 \\
0.000\end{array}$ \\
\hline $\operatorname{AR}(2)$ & & & & & & & $\begin{array}{l}1.7975 \\
0.0723\end{array}$ & $\begin{array}{c}-2.0615 \\
0.0393\end{array}$ & $\begin{array}{l}0.3323 \\
0.7396\end{array}$ \\
\hline
\end{tabular}

All equations include year dummies.

Robust standard errors in parentheses; *** $\mathrm{p}<0.01, * * \mathrm{p}<0.05, * \mathrm{p}<0.1$

Source: Authors calculations based on TURKSTAT (2015) data. 
Figure 1. Disaggregated Capital Structure

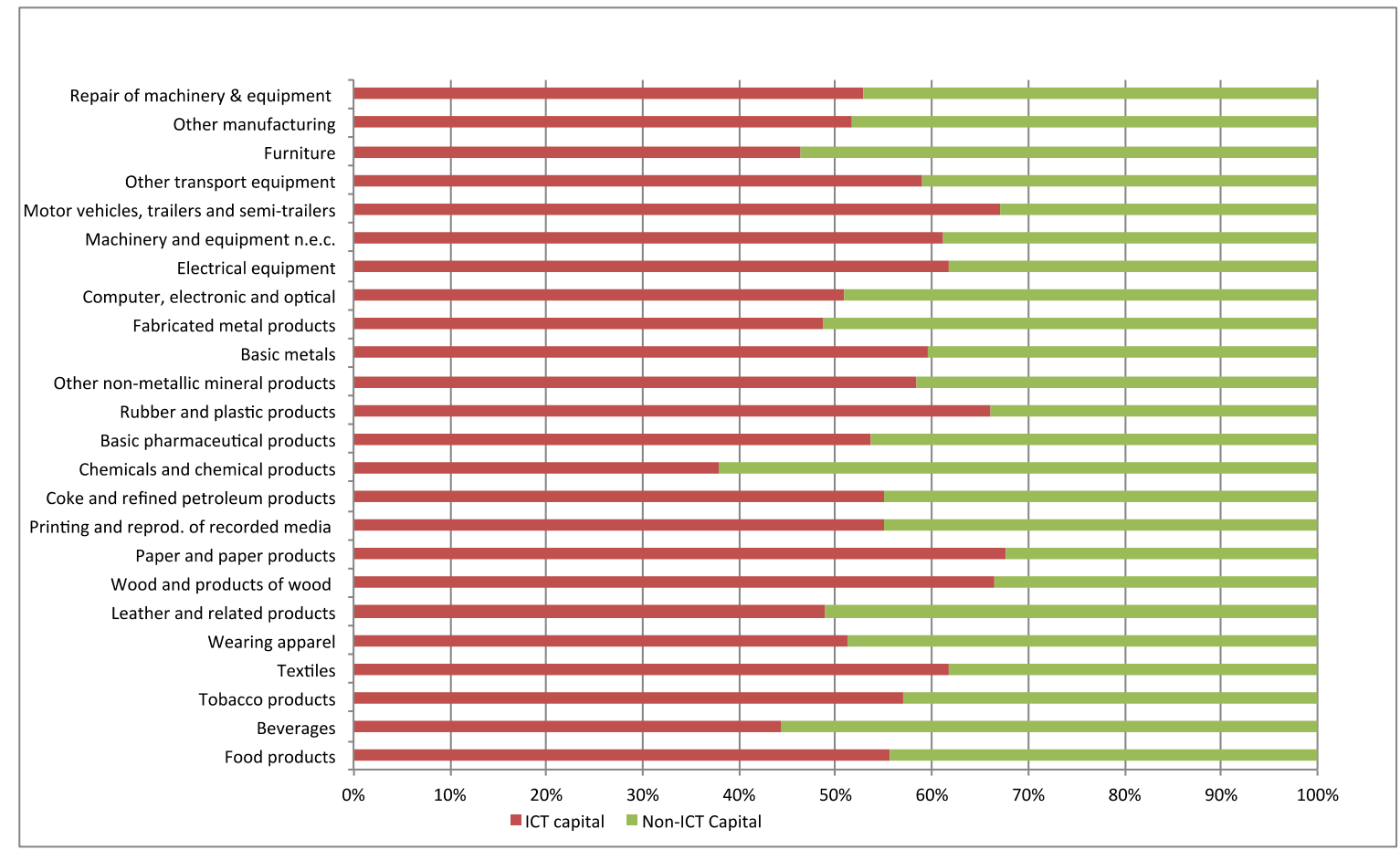

Source: Authors calculations based on TURKSTAT (2015) data. 
Figure 2. Factor input contributions (ICT and non-ICT capital) to productivity growth, NACE Rev.2 (3-digit), 2004-2012 average

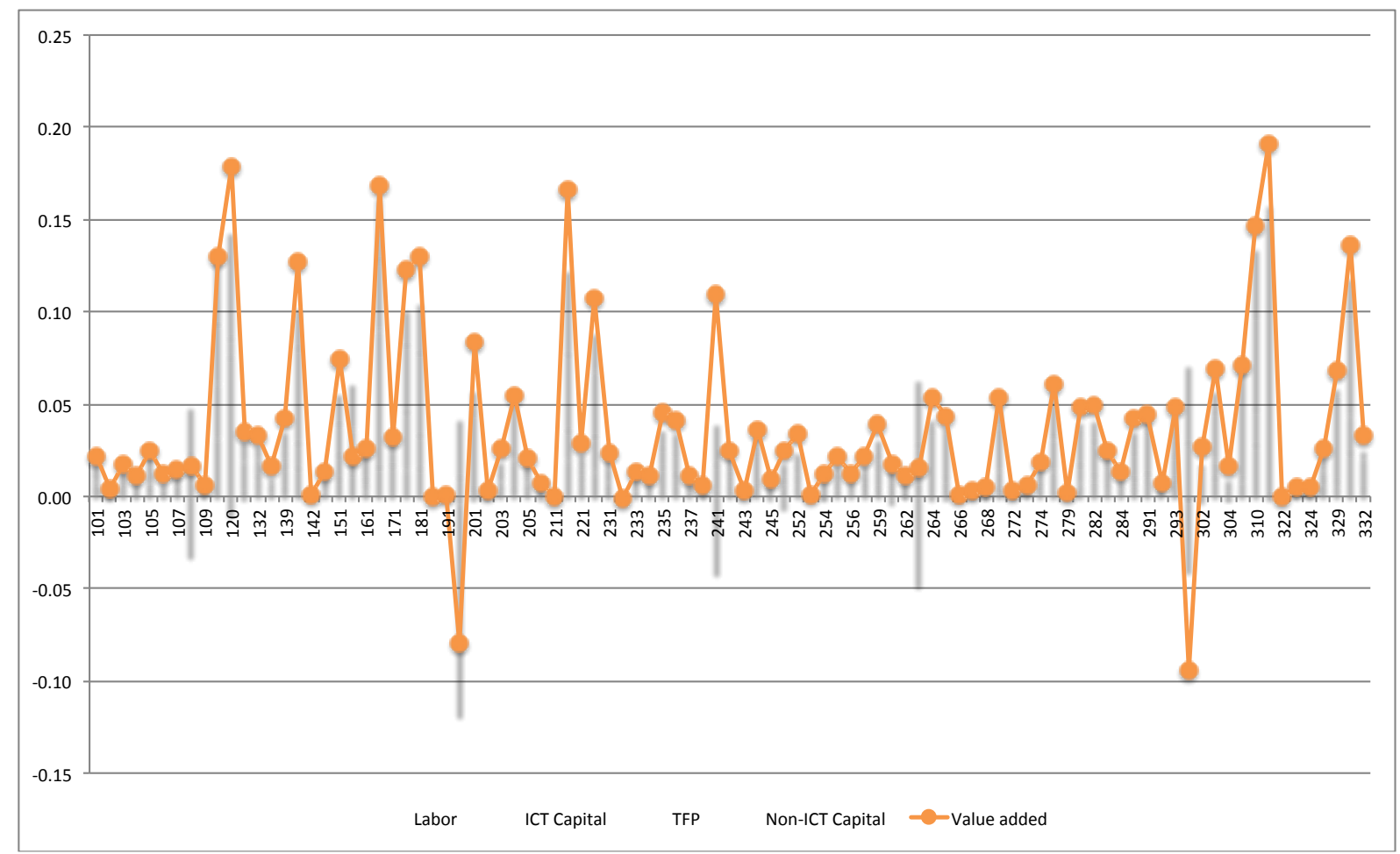

Source: Authors calculations based on TURKSTAT (2013) data.

Notes: In some of the sectors, the average contribution of inputs to value added growth has been calculated with 2004 data missing such as reproduction of recorded media (182) and manufacture of musical instruments (322). Moreover, for manufacture of basic pharmaceutical products (211) sector, four years data are missing including 2002, 2010 to 2012. 